MA MAJOR RESEARCH PAPER

\title{
THE ROLE OF COMMUNITY RADIO IN ENHANCING IDENTITY FORMATION AND COMMUNITY COHESION AMONG CARIBBEAN CANADIANS IN TORONTO
}

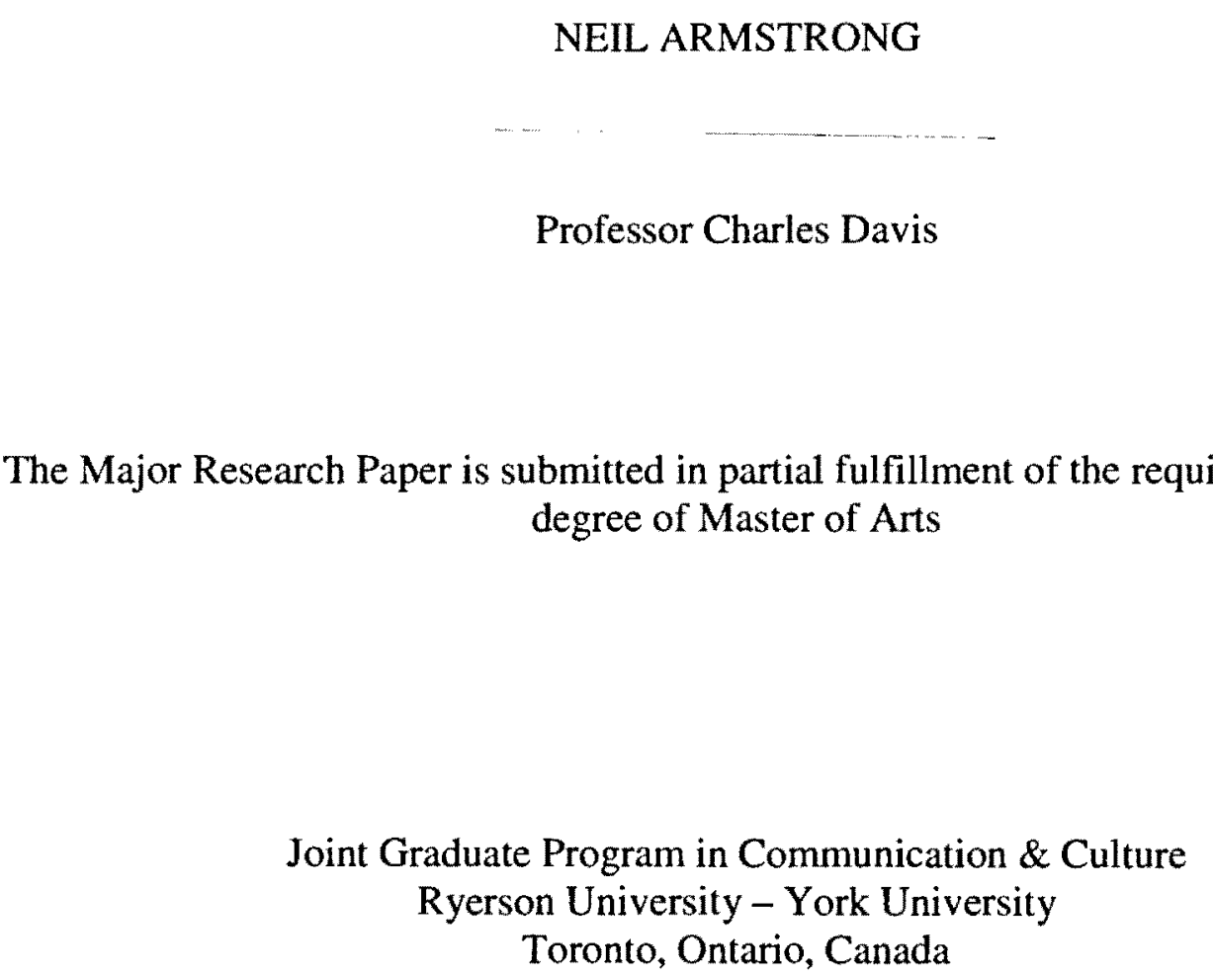

August 2010 


\section{TABLE OF CONTENTS}

$\begin{array}{ll}\text { Introduction } & 3\end{array}$

Theoretical Framework $\quad 9$

Theories of Identity Formation and Community Cohesion 20

Review of literature on alternative media 26

$\begin{array}{ll}\text { Methodology } & 30\end{array}$

Background of CHRY Radio 35

Background of CKLN Radio $\quad 42$

$\begin{array}{ll}\text { Findings } & 43\end{array}$

$\begin{array}{ll}\text { Conclusion } & 63\end{array}$

$\begin{array}{ll}\text { References } & 65\end{array}$

$\begin{array}{ll}\text { Appendix A } & 71\end{array}$

$\begin{array}{ll}\text { Appendix B } & 72\end{array}$

$\begin{array}{ll}\text { Appendix C } & 74\end{array}$ 


\section{Introduction}

Even as this research paper is being written, there is a news item on CBC Radio One that the Toronto-based, urban music radio station, Flow 93.5, has been sold to the CTV-owned CHUM-FM by Milestone Radio Inc. (Appendix A). Milestone Radio Inc., headed by Jamaica-born Denham Jolly, had struggled for a period spanning 12 years and three applications to the Canadian Radio-television and Telecommunications

Commission (CRTC) to own and operate a radio station. Many members of the Caribbean Canadian and Black communities wrote letters of support to the CRTC endorsing the application of Milestone Radio Inc. The radio station, Flow 93.5FM, was approved by the CRTC in 2000 , signed on in 2001 and between then and now changed its programming to meet market demands. Many from the Caribbean Canadian community who supported the initial application of Milestone Radio Inc. for the radio station expressed their disappointment that the radio station was not living up to what it promised initially - Caribbean and Black programming on mainstream radio. They had visions of the type of programs that they were accustomed to listening on community radio being transposed to this new commercial radio entity. There were complaints that there was not enough calypso, soca and reggae music being played on Flow 93.5FM, and that news and current affairs from the Caribbean, or related to the Caribbean were minimal or absent. Interestingly many of these complaints were made in calls to the offices of community-based campus radio stations and to radio programs on community 
radio. These complaints were also heard at community events, many of which were totally unrelated to media in purpose or intent.

At the time of writing this research paper, a letter from Fitzroy Gordon, the president of the Caribbean and African Radio Network Inc. (CARN), has been emailed to community media regarding the successful test transmission of 98.7 FM (Appendix B). In the letter, Gordon indicates that he is delighted with the feedback that he has received from listeners regarding the music played during the testing period. He said his journey to this point has taken 12 years. It is interesting to note that both men are from the Caribbean community - both born in Jamaica -- and have faced uphill battles in their efforts to apply to the CRTC for a licence to operate a commercial radio station. In the case of Milestone Radio Inc., its first two efforts were unsuccessful and licenses were granted to existing radio services. Its application was approved on its third attempt before the CRTC. CARN had applied in 2003 for $105.1 \mathrm{MHz}$ (CRTC 2003-20) to operate a commercial ethnic station which would target primarily the Caribbean and African communities. Its application was denied as the CRTC approved a French-language radio service as priority for the Greater Toronto Area. It subsequently received partial approval from the CRTC to operate $98.7 \mathrm{FM}$, with the conditionality that the $\mathrm{CBC}$ which operates 99.1 FM should approve CARN's technical requirements (Appendix C).

Although these are both commercial radio entities, the efforts involved by both men to own media in Toronto can be related to the marginality of Caribbean Canadians in this country. Both men have the foresight of owning the media to create a space for the presence of Caribbean and African, or Black Canadians in Canada's mediascape in Canada's largest city, Toronto. Unfortunately sometimes the dictates of the market 
economy result in promises to audiences being changed to meet the reality of the market. This was the case with the new Flow 93.5FM and Gordon has been pummeled by some supporters of CARN who were slightly reluctant to do so because of the lesson they learned from giving their initial support to Milestone Radio Inc.

In this paper I argue that community radio, which includes community-based campus radio (also known as campus/community radio), rather than commercial radio, remains the real alternative terrain where Caribbean Canadians can actively participate in the programming as producers and listeners, to tell their stories, hear their music, and have a stake in the ownership of the station. Burman (2010) posits that:

Migrants to Canada have overwhelmingly chosen to live in cities, Toronto above all others in the case of Jamaicans and other Caribbean migrants. Jamaicans make up the greatest portion of Caribbean migrants in Ontario by far: according to the 2006 Canadian Census, out of a total Caribbean-identified population in Ontario of about 300,000 residents, almost 200,000 residents identified as Jamaican, with 82 percent of those living in the Greater Toronto Area. Jamaican culture is the predominant Caribbean cultural influence in Toronto, except during Caribana, which celebrates various Caribbean influences. (Burman, 2010; p.15)

Given these demographics it is not surprising that Caribbean Canadians would want to see themselves and their issues reflected in the media. However, sad to say, because of their marginality in society they are absent from mainstream radio and therefore seek their opportunity for a voice in community radio. Community radio permit Caribbean Canadians to be involved in the creation of media as volunteers, and in some instances, are also the employment opportunity for Caribbean Canadians. Some are paid staff 
members - though there is very few paid staff at community radio stations - in the roles of operations coordinator, program coordinator, news director, spoken word coordinator, advertising/sales manager, technical/production coordinator and fundraising coordinator. It is true that Jamaican culture is the predominant cultural influence in Toronto (Burman, 2010 ) as is evident in not only the number of programmers (hosts of radio shows) who are Jamaica-born, or of Jamaican descent. But it is also evident that many people from the other Caribbean countries, or who are of Caribbean descent are involved as programmers and listeners at CHRY Radio and CKLN Radio.

As Berrigan (1977) posits, "Community media, whether on radio or television, are not a panacea. Participation is not the answer to all social problems (p. 142)". I am making the claim that community radio, in particular community-based campus radio, provides an important outlet for Caribbean Canadians to inscribe themselves into the broadcasting system of Canada. Girard (1992) argues that when community radio succeeds, "its broadcasts are marked with a passion rarely seen in commercial or largescale State media." He further observes that: "This passion arises out of a desire to empower listeners by encouraging and enabling their participation, not only in the radio but in the social, cultural and political processes that affect the community (Girard, 1992)."

This paper examines the important role that two community-based campus stations - CHRY 105.5FM and CKLN 88.1FM -- play in community cohesion and identity formation in the Caribbean Canadian community in Toronto. The research questions are: What roles do community media play in the lives of Caribbean-Canadians in Toronto?; How do Caribbean Canadians access these media to tell their stories or hear 
their voice?; How do these media outreach to the large Caribbean Canadian community in Toronto?; How do they describe the relationship that they have with CHRY 105.5FM and CKLN 88.1FM; and, Do these media affirm the marginalized status of Caribbean Canadians, or are they sites of transformation for Caribbean Canadians daring to contest their exclusion from mainstream radio? These radio stations readily accommodate people, including many on the margins, who are not represented in mainstream media the public broadcaster, the Canadian Broadcasting Corporation (CBC), or private commercial radio stations. They are the employers of many immigrants, mainly volunteers, who face barriers because of their Caribbean accents, lack of a Canadian accent, and the lack of "Canadian experience". The 'othering' of these immigrants has pushed/pulled them to these community-based campus radio stations where they find a voice to challenge oppressive systems from outside and within. These are communityenhancing spaces where the Caribbean diaspora will hear familiar genres of music reggae, soca, calypso, ragga, zouk - and accents/languages (Spanish, French, Creole) of the multicultural and multilingual Caribbean diaspora in Toronto.

According to Skinner (2009) in 2007 there were 109 community stations operating in Canada (CRTC, 2008), and licensees are expected to help promote community access by informing the public of opportunities for participation and providing training to those who wish to participate. In 2007, there were 41 community stations based on university campuses operating in Canada (Skinner, 2009). Skinner argues that alternative media, which include community radio, have a different focus from mainstream media: "They generally operate under a different set of news values 
than the dominant media, and they provide ways of seeing and understanding events that are marginalized or not available there" (Skinner, 2009).

This research is worth doing to provide an understanding of how people who are marginalized by mainstream media, in this case Caribbean Canadians, seem to find a certain kind of familiarity or recognition in community media, especially communitybased campus radio stations. It is through these media that most of their discussions and debates about issues affecting their lives take place. Bailey, et al., (2008) underscore the role that 'alternative media' or 'community media' play in providing a sense of identity and belonging.

We believe 'alternative' communication is important for daily life, for personal and collective politics, and for our sense of identity and belonging. This sense of belonging takes diverse forms: participation in more formal 'politics' as well as in the banality of daily life, for instance, the ability to have one's voice heard at a Sunday open market. At all those levels alternative media are inclusive of and go beyond the political realm and reach the everyday life of individuals and communities. (Bailey, et al., 2008; p. xi)

Many Caribbean Canadians gain a sense of identity and belonging through their connection with community radio in the Greater Toronto Area. I think the results of my research will be important to policy makers in the federal government and will help those who manage these media to solicit funding for their continued operation. Listenersupported, on-air fundraising drives are important features of all community-based campus radio. My research will help them to make a stronger case for more funding. 


\section{Theoretical Framework}

Given the different genres of Caribbean music, the different Caribbean accents and the number of open talk-format shows that allow the community to participate in programming, many people of Caribbean descent gravitate towards CHRY FM and CKLN FM. Theorist Raymond Williams, in his book, Culture and Materialism: Selected Essays, writing on the complexity of hegemony notes the significance of alternate discourses in the dominant culture framework.

Thus we have to recognize the alternate meanings and values, the alternative opinions and attitudes, even some alternative senses of the world, which can be accommodated and tolerated within a particular effective and dominant culture. This has been much under-emphasized in our notions of a superstructure, and even in some notions of hegemony. And the under-emphasis opens the way for retreat to an indifferent complexity. (Williams, 2005, p.39)

It is significant to note that although the CRTC initially applied the policy of commercial FM radio stations to the operation of community-based campus stations, it was cognizant of the role that these stations play as alternative media. The CRTC expects alternative news and viewpoints, and diverse programming that cater to marginalized communities. As a result of this mandate CHRY-FM has developed a loyal and dedicated core of radio supporters who tune in to the station for its Caribbean and other niche programming. 
Williams is also aware of the fact that there are some practices that go beyond the limits of the dominant culture:

There is clearly something that we can call alternative to the effective dominant culture, and there is something else that we can call oppositional, in a true sense. The degree of existence of these alternative and oppositional forms is itself a matter of constant historical variation in real circumstances. In certain societies, it is possible to find areas of social life in which quite real alternatives are at least left alone. (If they are made available, of course, they are part of the corporate organization.) The existence of the possibility of opposition, and of its articulation, its degree of openness, and so on, again depends on very precise social and political forces. (Williams, 2005, p. 40)

Many of the broadcasters and volunteers at CHRY FM and CKLN FM view the work that they do as part of the discourse in creating an alternative source to the dominant culture. Like Pacifica Radio in the USA, community-based campus radio stations try to air views and news that are unheard or absent in mainstream media. These radio stations also strengthen their links with communities by joining in their celebrations and telling their stories from the margins. CHRY has been doing remote broadcasts from the annual Driftwood Community Festival for many years, it has held town-hall meetings to discuss pertinent community concerns, and in the late 1980 s/early 1990 s did a few broadcasts from the premier celebration of Caribbean culture in Canada, Caribana. CKLN has also done remote broadcasts from Caribana and from the annual Pride Parade which includes Caribbean Canadians. There were instances in which community organizations would hold closed-door meetings to discuss issues of concern. Mainstream media would be 
barred from these sessions but CHRY and CKLN would be welcomed because they were seen as a part of the community and having a vested interest in the lives of residents.

In The Practice of Everyday Life, Michel de Certeau, also alludes to creation of a space to carry out alternative or oppositional discourses. He sees this as a form of resistance:

Innumerable ways of playing and foiling the other's game [...], that is, the space instituted by others, characterize the subtle, stubborn, resistant activity of groups which, since they lack their own space, have to get along in a network of already established forces and representations. People have to make do with what they have. In these combatants' stratagems, there is a certain art of placing one's blows, a pleasure in getting around the rules of a constraining space. (de Certeau, 2002, p.18)

In many ways volunteers at community-based campus radio stations, CHRY-FM and CKLNFM in particular, are engaged in a way of subverting and diverting the system to create their own survival tactics. Not hearing others like themselves on mainstream radio in Toronto, CHRY and CKLN volunteers have opted to create spaces at these radio stations which allow them to be themselves. Even as the dominant commercial radio broadcasting structure has failed to represent their presence in Toronto, people of the Caribbean diaspora are ensuring that their identity is acknowledged and documented in Canada's broadcasting system.

As far as the Caribbean Canadian community is concerned, its close relationship with CHRY and CKLN is evident in the Caribbean inflections heard in the station 
identifications, public service announcements and advertisements. Every year during their annual fundraising drive, many people from the community demonstrate their support by making pledges to the radio stations through their favourite programs. In many ways these participants in the radio station are inscribing themselves - writing the self -- in the radio broadcasting scene in Toronto.

Programmers at CHRY and CKLN are participating in métissage, a concept that Francoise Lionnet, in her book, Autobiographical Voices: Race, Gender, Self-Portraiture, alludes to as a space where diversity is affirmed. She expounds on the concept of métissage by stating that:

Within the conceptual apparatuses that have governed our labeling of ourselves and others, a space is thus opened where multiplicity and diversity are affirmed. This space is not a territory staked out by exclusionary practices. Rather, it functions as a sheltering site, one that can nurture our differences without encouraging us to withdraw into new dead ends, without enclosing us within facile oppositional practices or sterile denunciations and disavowals. For it is only by imagining nonhierarchical modes of relation among cultures that we can address the crucial issues of indeterminacy and solidarity. (Lionnet, 1989, p. 5) Programmers at CHRY and CKLN are re-visioning their place and space within the dominant radio broadcasting system in Toronto, but doing so through the communitybased campus radio stations system. Lionnet notes that: "If, as Teresa de Lauretis has pointed out, identity is a strategy, then métissage is the fertile ground of our heterogeneous and heteronomous identities as postcolonial subjects" (Ibid, p.8). The volunteers at CHRY FM and CKLN FM are conceptually embracing métissage to 
maintain their identities as postcolonial subjects who have something to say - Caribbean cadences and all -- on the airwaves of Canada's radio broadcasting system.

The National Campus and Community Radio Association, on its website, notes that, "we believe that the airwaves of Canada belong to the people. The public is made up of many communities." It sees the role of community-based campus radio stations or community-access radio as one of accommodating all under-represented voices.

There is no "voice" of community-access radio. We are all voices. There is no style that we expect our members to follow. The programmers who produce cultural programs from out of the diverse ethnicities and backgrounds that make up our towns and cities are dedicated to providing their own community with a voice. The advances of the Internet have allowed some of these to produce shows at our stations that are aimed at other countries. They do this without requiring public broadcast dollars and directives from the CRTC or the Broadcast Act. They are wonderful representatives of Canada to the world. (www.ncra.ca)

The diversity of voices is important to community-based campus radio stations. The appropriation of a 'voice' for Canada's mosaic is eschewed and programmers at community-based campus radio stations are encouraged to fully express themselves in their own voices. Antonio Gramsci (2000) notes the importance that language plays in identity formation.

Language also means culture and philosophy (if only at the level of common sense) and therefore the fact of 'language' is in reality a multiplicity of facts more or less organically coherent and co-ordinated. At the limit it could be said that 
every speaking being has a personal language of his own, that is his own particular way of thinking and feeling. Culture, at its various levels, unifies in a series of strata, to the extent that they come into contact with each other, a greater or lesser number of individuals who understand each other's mode of expression in differing degrees, etc. (Gramsci, 2000, p. 347)

The listeners of Caribbean descent who tune into the Caribbean programming at CHRY Radio and CKLN Radio are able to rally around the familiar modes of expression which remind them of their homelands. The Caribbean programming at CHRY and CKLN offers listeners a personal connection with the programmers. This is evident in the telephone calls from listeners to request their favourite songs or to express their displeasure with specific songs, and their very vocal contributions to discussions about current affairs on these shows. A unique element of the Caribbean programming is that a music show does not only feature music exclusively but will incorporate spoken word and caller interaction which engage the listening community to feel integrally involved in the program. Issues emanating from the policies and actions of politicians on Parliament Hill, Queen's Park and City Hall are contextualized by programmers and listeners in relation to their impact on the Caribbean Canadian community or black community in Toronto.

Canadian media guru Marshall McLuhan (1964) alludes to the intimate connection that listeners to radio have with on-air programmers in his book, Understanding Media: The Extensions of Man.

Radio affects most people intimately, person-to-person, offering a world of unspoken communication between writer-speaker and the listener. That is the 
immediate aspect of radio. A private experience. The subliminal depths of radio are charged with the resonating echoes of tribal horns and antique drums. This is inherent in the very nature of this medium, with its power to turn the psyche and society into a single echo chamber. The resonating dimension of radio is unheeded by the scriptwriters, with few exceptions. (McLuhan, 1964, p. 299) The subliminal element of radio is what draws people of the Caribbean diaspora to CHRY and CKLN where they hear the "resonating echoes of tribal horns and antique drums" of Caribbean culture. McLuhan is aware of the pivotal and changing role that radio plays in the lives of individuals, the central role of the disc-jockeys and the integral use of the telephone in radio broadcasting.

Since TV, radio has turned to the individual needs of people at different times of the day, a fact that goes with the multiplicity of receiving sets in bedrooms, kitchens, cars, and now in pockets. Different programs are provided for those engaged in diverse activities. Radio, once a form of group listening that emptied churches, has reverted to private and individual uses since TV. The teenager withdraws from the TV group to his private radio.

This natural bias of radio to a close tie-in with diversified community groups is best manifested in the disc-jockey cults, and in radio's use of the telephone in a glorified form of the old trunk-line wire-tapping. (McLuhan, 1965, p. 306) McLuhan's assertion of the manifestation of "disc-jockey cults" is evident at outdoor broadcasts where listeners will show up to see their favourite on-air music programmer, or attend any public event where the disc-jockey is playing music. On any given day, the 
telephone is their mediated connection with the programmer in the radio studio but in a public space, they can have direct contact with the disc-jockey.

In its news and public affairs programming, CHRY has developed what it calls "its own news strategy suitable for our situation and our community." It elaborates further on this strategy:

Our focus is on events and issues of public concern to the local community. We provide a voice to underrepresented groups, as well as presenting an alternative perspective on issues of public concern. CHRY stresses investigative reporting and analytical coverage. (CHRY Application to Renew Licence, 1990)

Extending its mandate to provide a voice for underrepresented groups, the radio station also focused on international affairs impacting lesser developed countries which it said are "usually given short shrift from mainstream media" (CHRY Application, 1990). It describes its flagship news program, News Now, as exploring "how the experiences of other parts of the world are viewed here in North York and the Greater Toronto Area". The Caribbean region, though a major hub for Canadian tourists, is rarely covered in mainstream media unless a country is threatened by a hurricane, Canadian peacekeepers are being sent to Haiti to help stabilize the situation there or Cuba's president Fidel Castro speaks. CHRY and CKLN recognize the importance of reporting stories related to the Caribbean to the Caribbean diaspora in Toronto. Often times, there is direct contact with grassroots people in these countries who can give a different perspective from that offered by the authorities. 
Though experts are not shunned there is a premium placed on including ordinary community members in the reportage of issues.

Our news team is representative of our area's cultural, social, and linguistic mosaic. CHRY does not discourage a variety of accents, but rather encourages them. Similarly, interviewees are selected first and foremost for their relationship and knowledge of a particular issue, irrespective of their academic or professional credentials. While experts from York University and local politicians regularly appear on this program [News Now], they are joined by individual residents without public portfolio or position as 'grassroots' community activists or organizers. (CHRY Application to Renew Licence, 1990)

Michel de Certeau seems to favour the ordinary individual over the expert when he posits that:

"Since he cannot limit himself to talking about what he knows, the Expert pronounces on the basis of the place that his specialty has won for him. In that way he inscribes himself and is inscribed in a common order where specialization, as the rule and hierarchically ordering practice of the productivist economy, has the value of initiation. Because he has successfully submitted himself to this initiatory practice, he can, on questions foreign to his technical competence but not to the power he has acquired through it, pronounce with authority a discourse which is no longer a function of knowledge, but rather a function of the socioeconomic order. He speaks as an ordinary man, who can receive authority in exchange for knowledge just as one receives a paycheck in exchange for work." (de Certeau, 2002, p.8) 
Earlier in his work, The Practice of Everyday Life, de Certeau noted that "The approach to culture begins when the ordinary man becomes the narrator, when it is he who defines the (common) place of discourse and the (anonymous) space of its development" (de Certeau, 2002, p.5). At CHRY and CKLN, there is an awareness that ordinary men and women play important roles in narrating their stories and defining places of discourse on the airwaves and spaces for their culture to develop.

Jeffrey Klaehn, editor of Filtering The News: Essays On Herman and Chomsky's Propaganda Model, notes the importance of the role of alternative media which is similar to that articulated by CHRY and CKLN.

In [Noam] Chomsky's view, individuals who wish to actively pursue a course of intellectual self-defence will also need to gain access to independent media whenever possible. This is crucial, Chomsky suggests, because the mass media routinely block information and reproduce dominant representations. Chomsky contends that individuals do not require political scientists to explain "political affairs' to them. The alleged complexity, depth and obscurity of these questions is part of the illusion propagated by the system of ideological control, which aims to make these issues seem remote from the general population to persuade them of their capacity to organize their own affairs and understand the which they live without the tutelage of intermediaries. (Klaehn, 2006, p.17)

Commenting on the issues of identity and culture shock, York University professor, Frances Henry, in her book, The Caribbean Diaspora in Toronto: Learning to Live with Racism, quotes a song, 'Culture Shock' by calypsonian Lord Cosmos, which says in part: 
They make a man suffer,

People using knife and fork to eat roti,

They say I'm overqualified with one degree,

On a crowded bus, the seat next to me empty

They say all Black people look just like me,

I switch on the radio and can't hear my soca,

When they say all West Indians come from Jamaica,

That is Culture Shock! ... (Frances Henry, 1994, pp. 45\&46)

Lord Cosmos has documented the reality of Caribbean people immigrating to Canada and not hearing their culture, in this case soca music, on radio. Henry notes that: "Most of the surveys, polls, and studies that have been conducted over the years in Canada regarding multiculturalism and multiracialism generally come to similar conclusions. Racial minorities express more dissatisfaction with life in Canada than do other ethnic groups" (Henry, 1994, p. 53).

York University professor Carl James in the book, Talking about Identity: Encounters in Race, Ethnicity, and Language, notes that the question, "Who's Canadian, Anyway?" is a key to the themes raised throughout the book:

[...], particularly when people continue to be asked "Where are you from?" or to be grilled about their "accents," skin colours, languages, names or ethnic origins. Inherent in the questioning is the view that such people are not "Canadians." The experiences detailed here challenge us to think of Canadians as having different colours and accents, and as speaking different languages. No one individual, then, 
is more "Canadian" than another. On the contrary, some individuals may be more consciously Canadian because they have made a deliberate choice to live in this country; so for them being Canadian is not simply a matter of an accident of birth. (James \& Shadd, 2001, p. 5)

Community-based campus radio stations, like CHRY and CKLN, are countering the "othering" that is implicit in these questions by allowing people of Caribbean descent to construct their identities in this society.

\section{Theories of identity formation and community cohesion}

Henry (1994), in her book, The Caribbean Diaspora in Toronto: Learning to Live with Racism, notes that:

Differential incorporation can be applied to the Caribbean people in Canada because as people of colour, they do not readily fit into this basically White society. Moreover, since a proportion of the population, especially secondgeneration youth, is increasingly becoming marginalized social class is also becoming a differentiated factor. Because of colour, and to some extent, class, Caribbean people occupy a marginal position. Their marginality in Canada and especially in Toronto will be demonstrated by such indicators as income data, the findings of employment discrimination research, and allegations of institutional and individual racism directed at this community. (Henry, 1994: p.13)

Henry (1994) also notes that the community response to racism includes several innovative mechanisms, including developing services to meet their needs. She writes:

By creating their own institutions, they are attempting to maintain aspects of their culture and ethnicity. They are becoming part of the pluralistic structure of the 
Canadian society; they do not attempt to assimilate. Assimilation is impossible in view of the racial barriers that lead to differential treatment. If anything, Caribbean people wish to be a part of the plural structure of society while retaining those aspects of their ethnicity and culture that are important to them. (Henry, 1994: p.278)

I am arguing that it is the position of marginality that has led Caribbean Canadians in Toronto to become media makers and media users of community radio. They are ensuring that their voices are heard and that their cultural retentions - language, identity, music - are retained in the community mediascape.

In "Creating Community with Media: History, Theories and Scientific Investigations," Nicholas W. Jankowski (2002) notes that in the late 1960s and early 1970s a new "thrust of interest developed for geographically defined as well as spatially disperse groups to employ these communication technologies [portable video recording technology and cable television distribution systems] for community initiatives and actions (p.36)." Noting that the media in these contexts were coined 'community media', Jankowski further posits that: "Community members are generally involved in all facets of station activities and exercise control over day-to-day and long-range policy matters. (Jankowski, 2002; p.36)

Referring to an overall assessment of a national experiment with community electronic media in the Netherlands, Jankowski notes that, "the researchers suggest that the contribution of community media to community-building processes worked best in those situations where a sense of community was already well established (Hollander, 1982; 
Stappers et al., 1992). In residential areas short on social capital, it seems as if community media can do little to "make things better" (see also Jankowski et al., 2001).

Manuel Castells in The Information Age: Economy, Society and Culture, Volume II, The Power of Identity (1997) in discussing the construction of identity notes that “identity is people's source of meaning and experience (Castells, 1997; p.6)." He further posits that: "By identity, as it refers to social actors, I understand the process of construction of meaning on the basis of a cultural attribute, or related set of cultural attributes, that is/are given priority over other sources of meaning. For a given individual, or for a collective actor, there may be a plurality of identities (Castells, 1997; p.6)." Castells also posits that from a sociological perspective, all identities are constructed. He notes:

The real issue is how, from what, by whom and for what. The construction of identities uses building materials from history, from geography, from biology, from productive and reproductive institutions, from collective memory and from personal fantasies, from power apparatuses and religious revelations. But individuals, social groups, and societies process all these materials, and rearrange their meaning according to social determinations and cultural projects that are rooted in their social structure, and in their space/time framework. I propose, as a hypothesis, that, in general terms, who constructs collective identity and for what, largely determines the symbolic content of this identity, and its meaning for those identifying with it or placing themselves outside of it. (p.7) 
Castells emphasizes that the social construction of identity always takes place in a context marked by power relationships. He proposes a distinction between three forms and origins of identity building: legitimizing identity, resistance identity, and project identity. Resistance identity is generated by those actors that are in positions/conditions devalued and/or stigmatized by the logic of domination, thus building trenches of resistance and survival on the basis of principles different from, or opposed to, those permeating the institutions of society (Castells, 1997). The author notes that identity for resistance leads to the formation of communes, or communities and that, "This may be the most important type of identity-building in our society. It constructs forms of collective resistance against otherwise unbearable oppression, usually on the basis of identities that were apparently, clearly defined by history, geography, or biology, making it easier to essentialize the boundaries of resistance (Castells, 1997; p.9)."

Writing of the worldwide emergence of community, alternative, oppositional, participatory and collaborative media practices, Mark Deuze in "Ethnic Media, community media and participatory culture" (Deuze, 2006) underscores the importance of community members creating their own media:

In this context, becoming the media refers to the trend among people all over the world - especially in Western 'liquid modern' capitalist democracies like North America, Europe (West, East and Central), southern Africa and Australasia - to be increasingly engaged in some type of media-making on and of their own. It must be noted that becoming the media also refers to a perspective on the media audience as active producers of meaning from within their own cultural context (Barker, 2003: 325 cited in Deuze, 2006). 
Referencing Castells' definition of identity as being "people's source of meaning and experience", Caribbean Canadians in Toronto, given the power relationships in society, are involved in what he describes as resistance identity. That is, they are in "positions/conditions devalued and or stigmatized by the logic of domination, thus building trenches of resistance and survival on the basis of principles different from, or opposed to, those permeating the institutions of society [...] (Castells, 1997)." Their meaning-making is part of their identity formation process. As Deuze (2006) notes, "becoming the media also refers to a perspective on the media audience as active producers of meaning from within their own cultural context" (Deuze, 2006). In "Reimaging National Belonging With Community Radio", Mojca Plansak and Zala Volcic note that:

The media are seen as a crucial player in the formation of identities, based on their role in providing space for (community) discussion and in helping sustain, suppress, or simply deal with cultural memories, myths, and collective fears, hopes, and desires for the future (Billing, 1995; Morley, 2000; Williams, 1977, 1980) (Howley, 2010: p.78)

Examining the question of how countries and communities recover from episodes of social change, political collapse, or violence and of how, precisely the media should help in this process, Plansak and Volcic note that: "In particular, community media (media produced for and by different community groups) have often been viewed as offering alternative (nonnationalistic and noncommercial) spaces of belonging" (Howley, 2010: p.78). 
My paper examines the ways in which Caribbean Canadians in Toronto use community radio for community discussion and to "[...] sustain, suppress, or simply deal with cultural memories, myths, and collective fears, hopes, and desires for the future" (Howley, 2009: p.78). In becoming producers of media, they have created a space of belonging.

Cultural theorist Stuart Hall (1993) implores us to think of identity as, "[...] a 'production', which is never complete, always in process, and always constituted within, not outside, representation" (Rutherford, 1993, p.222). Identity formation, therefore, among Caribbean Canadians is always becoming. Writing of the Caribbean diaspora, Hall notes that:

The diaspora experience as I intend it here is defined, not by essence or purity, but by the recognition of a necessary heterogeneity and diversity; by a conception of 'identity' which lives with and through, not despite, difference; by hybridity.

Diaspora identities are those which are constantly producing and reproducing themselves anew, through transformation and difference. One can only think here of what is uniquely - 'essentially' - Caribbean: precisely the mixes of colour, pigmentation, physiognomic type; the 'blends' of tastes that is Caribbean cuisine; the aesthetics of the 'cross-overs', of 'cut-and-mix', to borrow Dick Hebdige's telling phrase, which is the heart and soul of black music. (Rutherford, 1993, p. 236)

Community-based campus stations are cognizant of the heterogeneity and diversity of the Caribbean diaspora which is reflected in their programming of music and spoken word programs. They are welcoming spaces for the hybridity of Caribbean Canadians who are 
"constantly producing and reproducing themselves anew, through transformation and difference" (Rutherford, 1993, p.236).

\section{Review of related literature on alternative media which includes community radio}

Nico Carpentier (2008) posits that alternative media contribute to the development of the discourse of the communicative city, which is one of the representational regimes that aim to produce the city, its inhabitants and its communities. Carpentier provides an overview of four distinct approaches towards alternative media (the community media model, the model of alternativeness, the civil society media model and the rhizomatic media model), which show the importance of the participatory and the translocal for alternative media theory and for the communicative city. The community media model and the model of alternativeness are used in my paper to show how community members participate in and through community media to create a voice for themselves in a world of media mergers and less access to privatized media.

Charles Fairchild (2001) posits that community radio has a contradictory and conflicted presence in the North America media sphere. He notes that, "it is an oppositional enterprise using a "forgotten medium" within a very difficult and contentious economic and cultural environment". Fairchild's analysis of the media sphere in North America provides insight into challenges encountered by community radio and issues of access resulting from the privatization of broadcasting systems and 
globalization. His hypothesis is helpful to my thesis that community media, especially community-based campus radio, are accessible to marginalized communities and contribute to community cohesion. In his Master's thesis (1993), Fairchild examines the importance of the local community in the programming of CHRY-FM (York University) and CIUT (University of Toronto). Fairchild shows that community radio stations in Toronto are examples of specifically local organizations engaged in a generally collective, accessible and non-hierarchical cultural production which inherently challenges the limitations of most media organizations. Fairchild notes that these institutions exist to provide listeners and participants the means to direct the production of radio programming which best reflects the interests of communities not represented in major media outlets. Again, the case is made for the participation of community members in the programming and operation of community media. This paper supports my thesis that as community members speak with each other in these spaces they create community cohesion.

Cecil Foster (1996), an author and former journalist, now professor at the University of Guelph, explores what it means to be black living in Canada. Regarding media representation, he writes about the work of veteran $\mathrm{CBC}$ journalists, Dwight Whylie and Keeble McFarlance, who broke the colour bar and joined CBC Radio. He notes that their early retirement from the $\mathrm{CBC}$ meant the loss of a Caribbean accent on the national broadcaster. This indicates the paucity of broadcast personnel on the public radio and private commercial radio airwaves that are from the Caribbean, and strengthens my argument that Caribbean Canadians gravitate towards community media where they hear accents that are familiar with their identity. 
Departing from Habermas' theory of a bourgeois public sphere, Nancy Fraser (1990) envisions an alternative, post-bourgeois conception of the public sphere. She alludes to the many public spheres that were in existence in France and criticizes Habermas' focus on the bourgeois public sphere. Fraser notes that members of subordinated social groups - women, workers of color, and gays and lesbians - have repeatedly found it advantageous to constitute alternative publics. She describes these as "subaltern counterpublics in order to signal that they are parallel discursive arenas where members of subordinated social groups invert and circulate counterdiscourses, which in turn, permit them to formulate oppositional interpretations of their identities, interests and needs" (Fraser, 1990). My paper posits that these alternative publics are evident in the diverse volunteer-produced programs at community-based campus radio stations throughout Canada.

Bruce Girard, founder of AMARC (World Association of Community Radio Broadcasters), (1992), argues that the most distinguishing feature of community radio is its commitment to community participation at all levels. He notes that community radio listeners are the producers, managers, directors, evaluators and even the owners of the stations. Girard emphasizes that there is a desire to empower listeners by encouraging and enabling their participation, not only in the radio but in the social, cultural and political processes that affect the community. This supports my thesis about community participation.

German philosopher Jurgen Habermas (1989) defines the bourgeois public sphere as "the sphere of private people come together as a public; they soon claimed the public sphere regulated from above against the public authorities themselves, to engage them in 
a debate over the general rules governing relations in the basically privatized but publicly relevant sphere of commodity exchange and social labor." The public sphere is therefore a space where people, albeit the bourgeois, came together to publicly reason about the affairs of state. My paper posits that community media create a public sphere, though more likely similar to counterpublics (Nancy Fraser, 1990), for participatory communication and alternate discussions to happen between people and the media.

Rowland M. Lorimer and Donald Wilson (1988) make a case for the growing importance of community radio, "due in large part to the strong reactions by many people to the aggressive expansion of specifically American media worldwide, especially in Canada, Latin America, and the Caribbean". The writers note that community radio is "increasingly speaking in languages few have ever heard and speaking about things taken for granted or ignored for far too long and exists in places little valued, rarely seen, and only faintly heard". These media are no competition for direct broadcast satellites but the writers underscore the fact that they "are directed by the local population and made to serve their interests, needs, and desires". The thesis of the Lorimer-Wilson book is similar to that of my research topic, that community media, in the context of globalization and commercial media convergence, are accessible sites for community building.

Lisa Catherine Monk (1997) notes that a government policy to regulate campuscommunity radio stations in Canada was introduced just a few years before she began her research and this was new terrain to explore in research. Not much had been written about it. In 1991, the Canadian Radio-television and Telecommunications Commission (CRTC) conducted a complete review of these types of not-for-profit radio which play an important role in ensuring that Canadians receive a 'varied and comprehensive' radio 
service (Public Notice CRTC 1991). Like Fraser, Vincent Mosco (1996) discusses the difficulty of defining the public sphere and is critical of Habermas' concept of it by saying it was "hardly democratic or very public" (Mosco, 1996). Though using the concept of the public sphere, my paper will take into consideration its limitations and argue that oppositional spaces are created by community media for full citizen participation.

Using the example of $4 Z Z Z$, a community radio station located in Brisbane, Australia, Kitty van Vuuren (2006) reminds us that community media's role in encouraging local dialogue and building community identity is not immune from hegemonic processes. The author shows that while community media encourage sharing and participation among community members, they are also sites of exclusion, control, conflict and enmity. van Vuuren argues against the ideal of public sphere imagined as an area open and accessible to all people. She posits that community radio stations are best understood and evaluated from the perspective of their community development function. This article will help in my thesis of demonstrating that although community media can be sites of contestations, they play a pivotal role in the development of community, for example, the Caribbean-Canadian community, in Toronto.

\section{Methodology}

I used the case study methodology to explore the relationship between Caribbean programs at the community-based campus radio stations, CHRY 105.5 FM at York University and CKLN 88.1FM at Ryerson University, and the Caribbean Canadian listenership of the stations. These case studies describe, in-depth, the relationship 
between these listeners and the Caribbean programs at these radio stations. Creswell (1998) notes that "for a case study, the researcher should focus on an event, process, or program for which we have no in-depth perspective on this "case" (p.95). By focusing on these particular "cases", I am hoping to gain insights into the nexus of the medium of community radio and the Caribbean Canadian community in Toronto. Denscombe (2007) notes that "the prospects of getting some valuable and unique insight depends on being able to investigate things in a way that is different from, and in some senses better than, what is possible using other approaches" (p.36).

Some studies have been done on community media or alternative media in countries around the world but very little on community media, especially communitybased campus radio, in Canada. I chose CHRY 105.5 FM and CKLN 88.1FM - two of the three campus-community radio stations in Canada's largest city, Toronto. They both have substantial Caribbean programming but more so CHRY. These radio stations are also located in a city where the signal Caribbean Canadian event in Canada - Caribana -happens every year, drawing over one million people to Toronto, described by the United Nations as the most multicultural city in the world (www.unesco.org). I chose to do my research on community radio because I worked at CHRY $105.5 \mathrm{FM}$ in various management capacities for almost ten years and became very familiar with the role it plays in the community, especially the Caribbean Canadian community.

My research methods included one-on-one interviews and a review of documents to gain qualitative and quantitative data. Interviews were done with a total of 22 listeners, radio programmers and advertisers of both radio stations. These interviews permitted me to gain insights into things like people's opinions, feelings, emotions and experiences 
(Denscombe, 2007) as they relate to the radio stations. Eight radio programmers, 12 listeners and 2 advertisers were interviewed. The interviews afforded me privileged information (Denscombe, 2007) from key players at the radio station. These interviews were audio-tape recorded as well as documented by note-taking. The questions were open-ended and were asked in a setting comfortable to the interviewees. Identifying a challenge of one-on-one interviewing, Creswell notes that "the researcher needs individuals who are not hesitant to speak and share ideas and needs to determine a setting in which this is possible" (p.124). The participants in this research study were not hesitant to share information about their listening habits, and participation in community radio. By examining documents such as the constitution of the radio stations, mandate and goals, code of conduct, programming policies, volunteer recruitment and on-air funding drive campaigns, I also gained insights into the structural operation of the radio stations.

As a caveat, let me note that CKLN FM is at present in the process of reorganization after a hiatus of broadcasting and has been summoned by the CRTC to appear at a public hearing that will take place later in the year. As a result, the radio station is in a bit of disarray and historical documents cannot easily be found. I relied on documentation from the CRTC's website, the 2007/2008 program guide of CKLN, and its website, www.ckln.fm.

Using a triangulation of information (Creswell, 1998), this data allowed me to make comparisons with the findings derived from the interviews and the existing literature on community radio. With regard to the importance of validity in a qualitative study, Creswell (1998) suggests that: "triangulation of information - searching for the convergence of information - relates directly to "data situations" in developing a case 
study. It was also important for me to listen to the Caribbean programs to get a sense of what the programmers do and how they engage listeners.

I wrote descriptive reports of the audio-taped interviews which included informal notes and comments alongside the interviewees' words. Denscombe (2007) notes that these annotations can be based on the memories that come flooding back during the process of transcribing. Line numbering and coding (Denscombe, 2007) helped to locate different parts of the transcript and helped to navigate through to particular points in it. Some of the problems of transcription included difficulty in hearing what was recorded, interviewees not always speaking in finite sentences, and intonation, emphasis and accents used in speech are hard to depict in a transcript (Denscombe, 2007). In instances where the recording is difficult to hear, I took Denscombe's advice: "There is a fine dividing line here between the need to ditch these parts of the interview records and disregard them as worthwhile data, and the need to exercise some reasonable interpretation about what was actually said" (p. 197). Some quotes and extracts of the transcripts are used verbatim in the representation of the data.

Since the analysis of data involves an iterative process, it required me to go back and forth between stages, especially in relation to coding, interpreting, and verifying the data. Denscombe (2007) notes that the iterative process is important because "the development of theory, hypotheses, concepts or generalizations should be based on a process that constantly moves back and forth comparing the empirical data with the codes, categories and concepts that are being used" (p. 288). The 'raw data' were coded, categorized, themes and relationships among the codes and categories were identified, and I developed concepts, and arrived at some generalized statements. Denscomber 
(2007) notes that the final stage of the analysis requires the researcher to develop some generalized conclusions based on the relationships, patterns and themes that have been identified in the data.

With regard to the validity of the data analysis method (or what some researchers prefer to call 'credibility'), Denscombe recommends three methods of addressing matters of accuracy and the appropriateness of data qualitative researches - triangulation, respondent validation and grounded data. Denscombe (2007) also notes that one of the key benefits of qualitative research is that the findings will have been grounded extensively in fieldwork and empirical data. Where the reliability of the data analysis method is concerned, Denscombe notes that with qualitative research, the researcher's 'self' tends to be very closely bound up with the research instrument - sometimes an integral part of it. He writes that the question of reliability translates from 'Would the research instrument produce the same results when used by different researchers (all other things being equal)?' to 'If someone else did the research would he or she have got the same results and arrive at the same conclusions?'(p. 298). Denscombe posits that the research should reflect 'procedures and decisions that other researchers can 'see' and evaluate in terms of how far they constitute reputable procedures and reasonable decisions. As a check on reliability, he posits that this calls for an explicit account of the methods, analysis and decision making.

My research analyzes the data from the one-on-one interviews and review of documents to explore the relationship that Caribbean Canadian listeners have with CHRY 105.5FM's and CKLN 88.1FM's Caribbean programming. The generalizability of the findings of these case studies may be questioned but as Denscombe posits : "Research 
based on small numbers and qualitative data needs an alternative way of addressing the issue. This alternative way is what Lincoln and Guba (1985) have called 'transferability'. This is an imaginative process in which the reader of the research uses information about the particular instance that has been studied to arrive at a judgment about how far it would apply to other comparable instances"(p. 299).

It is also important in my analysis of the data to include a reflexive account by (me) the researcher concerning (my) the researcher's self and its impact on the research (Denscombe, 2007). Denscombe writes that: "There is a growing acceptance among those involved in qualitative data analysis that some biographical details about the researcher warrant inclusion as part of the analysis, thus allowing the writer to explore the ways in which he or she feels personal experiences and values might influence matters (p. 301).

\section{Background of CHRY Radio}

On March 30, 1987 in Decision CRTC 87-240, the Canadian Radio-television and Telecommunications Commission (CRTC) approved the application for a broadcasting license for a low-power English-language FM radio station at Downsview on the frequency $105.5 \mathrm{MHz}$, channel 288 , with an effective radiated power of 50 watts. York University campus radio, CJRY, student-funded radio station was approved by the CRTC in Toronto. The application of CKLN-FM, at the then Ryerson Polytechnical Institute (now Ryerson University), was approved in 1984, and the application for CIUT-FM at the University of Toronto was approved in 1987, six months before CHRY received approval. Noting that it is the general policy of the Commission to license only one 
student radio station in each official language in any given market, the CRTC digressed in approving the application of CJRY (now known as CHRY Community Radio Incorporated, CHRY-FM).

In this case, the Commission has taken into account the applicant's statement that the proposed station will make use of a low-power unprotected frequency and that it "would be the only station in its service area that devotes considerable amounts of its music programming to black music and folk music from different parts of the world". Further, the Commission was impressed with the innovative community and educational programming proposals contained in this application and the numerous interventions in support, including those from the other local student FM licensees. (Decision CRTC 87-240)

The Commission also noted that the radio station would "fill a need and add to the diversity and quality of programming currently available" (CRTC 87-240). It also noted that the application contained a number of commitments that reflect the Commission's objectives for student radio as outlined in Decision CRTC 75-247, including "the use of volunteer staff and the high level and diversity of spoken word programming" (CRTC 87-240)."

In its Policy Proposals for Community and Campus Radio (Public Notice CRTC 1991-118), the CRTC noted that it was "worthwhile to conduct a complete review of these types of not-for-profit radio, both of which play an important role in ensuring that Canadians receive a "varied and comprehensive" radio service." There were concerns raised about the use of the term "student radio," which some found pejorative. 
Although the Commission considered it appropriate to designate stations operated by broadcasters who are students as being student radio stations, some participants believe the term implies that participants are broadcasters in training rather than skilled practitioners of an alternative, but equally valuable style of broadcasting. (Public Notice CRTC 1991-118, p.7)

This, among other considerations, resulted in the CRTC redefining campus radio into two types: campus/community and instructional. Campus/community is a campus station that is not formally associated with a broadcasting course and its programming is produced primarily by volunteers who are either students or members of the community at large. CHRY-FM falls in this category. In expounding on the role of these stations, the CRTC noted that:

Over the past few years campus/community radio stations have increasingly involved members of the community, as well as students, in all aspects of operation. Because of the lack of government funding for English-language community radio stations, campus/community stations have moved to fill this community role. (Public Notice CRTC 1991-118, p.8)

The CRTC further defines campus/community stations as:

The primary role purpose of these stations is to provide alternative programming such as music not generally heard on commercial stations or the CBC (including traditional and special interest music as well as popular music), in-depth spoken word programming, and programming addressed to specialized groups with the community. Although students play a major role in programming, campus/community stations should also provide access to members of the 
community at large when their signals reach beyond the campus. Such stations also provide training in radio production to volunteers. (Public Notice CRTC $1991-118$, p.8)

CHRY-FM has demonstrated its commitment to fulfilling the mandate for campus/community stations outlined by the CRTC. In an oral presentation to the CRTC to intervene in an application by Robert Wood for a license to carry on an FM broadcasting undertaking in Toronto, on February 4, 1988, CHRY-FM representatives noted that: "As a result of our programming, policies, and general access to the airwaves by individuals and groups in our listening area, we work closely with our surrounding community." The president of CHRY Community Radio Inc., Mel Broitman, told the Commission of the important connection that the radio station had with the black community, including Caribbean diaspora, in Toronto. In his oral presentation, he said: As we noted in our original application to the Commission, citizens in our surrounding community make up a significant portion of the Afro-Canadian and Afro-Caribbean population of Toronto. Our close ties with this community is manifested in the tremendous involvement by community groups and individuals as both broadcasters and supporters of the station.

In the late 1980s CHRY was providing "well over 25 hours of 'Black' music spread throughout its schedule, including Jazz, Rhythm \& Blues, Gospel, Soul, Funk, Rap, Hip-Hop, Dance, House, Reggae, Calypso, Soca, and many forms of African music" (CHRY Application, 1990). Staff at the radio station noted that the response from the listening audience far exceeded their expectations, and they felt there was still more that they could do. In a letter, dated January 8, 1988, to the Secretary General of the CRTC, 
Mel D. Broitman, president of CHRY; Kaan R. Yigit, the program director and Pat Anderson, a board member of CHRY noted that, "CHRY is the only station in Toronto (and Canada) that devotes a minimum of $25 \%$ of its music-programming time to various forms of Afro-Canadian, Afro-Caribbean and Afro-American musics (hereinafter referred to as "Black-music"), including Blues, Jazz, R\&B, Reggae and Calypso" (Oral presentation to the CRTC, 1988).

Given the high percentage of "Black-music" played at CHRY-FM, it was not surprising that many of the volunteers came from the surrounding communities, predominantly Jane-Finch, which had a high concentration of immigrants, many from the Caribbean and Africa. The station also served the communities of Vaughan, Richmond Hill, as well as parts of Mississauga, Scarborough and Metropolitan Toronto. York University student Charles Fairchild, in his Master of Arts thesis, The Producers and the Produced: Community Radio in Toronto, notes the importance of the local community in CHRY-FM's programming.

CHRY's specificity has a lot to do with the local community, beyond which its signal is quite weak. CHRY is most closely associated with "Jane-Finch," a neighbourhood with a reputation as a centre of urban decay. This is largely based on the myths, lies and racist assumptions of urban living. But this neighbourhood is unusually broad and diverse, with people from over one hundred countries coexisting in a relatively confined area. (Fairchild, 1993, p. 180)

Fairchild also notes that "a large part of CHRY's success is the explicit focus on this one specific community, providing an obvious service for an obvious need (Fairchild, 1993, p. 181)." 
If one were to take a cursory look at the commercial radio broadcasting industry in Toronto, one would be hard-pressed to hear Caribbean accents on any of the stations in Toronto, including the public broadcaster, the CBC. In the $1990 \mathrm{~s}$, author and journalist (now professor at the University of Guelph), Barbados-born Cecil Foster had a show on CFRB 1010. Dwight Whylie, an announcer and journalist, (now deceased), and Keeble McFarlane, a news editor, both from Jamaica, were described as two of CBC National Radio's "most venerable faces and public voices (Cecil Foster, 1996, p.190)." Foster, in his book, A Place Called Heaven: The Meaning of Being Black in Canada, commenting on the early retirement of Whylie and McFarlane, noted that they broke the colour bar and joined $\mathrm{CBC}$ Radio. He noted that their departure also meant the loss of a Caribbean accent on the broadcaster:

For this public broadcaster there are bigger problems than just losing another two stalwarts. The mandate around the newsroom is doing more with less and in such a way that the listener will not notice any changes. Yes, something will be lost from not hearing the Caribbean cadence and nuances of a Dwight Whylie reading the news and weather on national radio. And Keeble McFarlane will be missed for his thoroughness in the newsroom, for keeping a watch for all those stray peccadilloes of grammar, pronunciation and on-air misuses of ethnic and other stereotypes. For he is one of the CBC's tireless language watchdogs. But to listeners, Keeble's departure will go largely unnoticed. Such is the lot of an editor working behind the scenes who only occasionally ventures out into the limelight as a reporter. (Foster, 1996, p. 190) 
Foster also noted that their departure "portend how any small gains that have been made in the past two decades to change the complexity and sensitivity of newsrooms in Canada can be wiped out with the stroke of a pen or with a resignation" (Ibid, p.192). Trinidad-born Carl Redhead, a former vice president of operations at CHIN Radio, once advised me as a budding journalist, newly arrived here from Jamaica in 1993, that given my Jamaican accent it would not be easy to find employment in mainstream radio stations in Toronto. A suggestion was made to go to the hinterlands, make a name for myself there in radio and then work my way back to Toronto's radio broadcasting scene. Redhead was one of the directors in Milestone Radio Inc. (headed by Denham Jolly) which tried for 12 years to establish a Black-owned commercial Urban-format radio station. After three attempts, the CRTC finally approved the group's application to operate FLOW 93.5 FM on June 16, 2000. On February 9, 2001, FLOW 93.5 was launched with its Urban format which it describes as "a diverse, cosmopolitan music format based on Rhythm and Blues music and related genres." It noted that this format is a modern-day reflection of the rich musical traditions of Black musicians and Blackinfluenced music over the past century. And even on this new radio station which received a huge support from African Canadians, many from the Caribbean community in Toronto, one is still hard-pressed to hear Caribbean accents. The loci of the Caribbean cadences heard on-air are the three campus/community radio stations in Toronto CHRY, CIUT and CKLN - and CHIN Radio, the first multicultural and multilingual station to be established in Ontario in 1966. Given the paucity of Caribbean voices on mainstream radio, it is not surprising that many people from the Caribbean diaspora have 
been attracted to CHRY-FM, which has a higher percentage of Caribbean programming that the other campus/community stations and CHIN Radio.

Grenada-born Orlando Sitney, programmer of the calypso show, Rockin' Soca, (heard on Saturday nights) was the first person to sign on after CHRY received its FM license in 1987. Twenty-one years later he is still doing his show, and so are others who were there from the beginning. So too are Luther Brown, a school principal, who hosts the show Caribbean Crucible on Sunday nights and Mortimer Price who hosts Calypso Spectacular on Sunday afternoons. Some of the longstanding shows at CHRY were Caribbean-focused - Calypso Sunrise, Delroy G Showcase and Cultural Experience.

\section{Background of CKLN Radio}

CKLN's program guide for 2007/2008 boasts that the station has been broadcasting for " 24 years $24 / 7$ " and states: "Since 1983 , we have been broadcasting, live-to-air, all that is community radio: direct, outspoken, experimental and expansive; politically, musically and culturally." The program guide further notes that: "The programming is produced almost entirely by a volunteer crew of over 250 , who come to CKLN from every neighbourhood and community of Toronto. Many volunteers are current or former students of Ryerson." Over the years, CKLN has used many themes for its on-air fundraising drive, including "underground radio" which described its literal location -underground in the basement of Ryerson University. But "underground radio" also meant underground in terms of the tactics used by the station to fulfill its mandate of being an alternative to mainstream media and the public broadcaster. 
In 2008, CKLN was in a state of disarray, and according to the radio station's website in 2008 and 2009 many programmers were forced out of the station and the station was off the air for several months in 2009. CKLN resumed live broadcasting on September 29, 2009. The CRTC had initially scheduled a public hearing (Broadcasting Regulatory Policy CRTC 2010-499) for May 12, 2010 but this was adjourned until later in the year because of a litigation involving CKLN which is now before the Ontario Superior Court of Justice.

In a letter dated June 2, 2010, to CKLN-FM Radio Inc., the CRTC states: As indicated in Broadcasting Notice of Consultation CRTC 2010-146 (the Notice of Consultation), it appears to the Commission that CKLN is presently in noncompliance with the Radio Regulations, 1986 (the Radio Regulations) and its conditions of licence. The Commission notes that these issues of non-compliance have existed for over a year. (CRTC letter, 2010-06-02)

In its correspondence with CKLN, the CRTC mentioned matters related to the governance of CKLN and the legitimacy of the current Board of Directors. Until the public hearing resumes the CRTC expects a report from CKLN on the maintenance of logs, logger tapes and music lists, as well as the filing of annual returns, any changes to the membership of the Board of Directors, and contact information for members of the Board of Directors.

Findings

A qualitative analysis of listeners to CHRY Radio at York University and CKLN Radio at Ryerson University indicates that many Caribbean Canadian listeners have 
found validation of their voices - their issues, ideologies, and representation -- in these radio stations. Many of the listeners who participated in an in-depth interview of their listening habits to community radio identified music, access, participation, and an outlet for their voice (self validation), as their main reasons for listening to community radio. These are some of the comments shared by various listeners about community radio: "They keep it real. There is a more personal touch. Community radio provides a space for our voice"; "You get content that you don't get in mainstream, plus I'm reflected. I see my community members on there, it is so accessible. I have easy access to the programmer and can comment instantly on issues"; and, "It was the only place that I could hear people who were concerned with the same issues that I had and shared some of my same political ideology. There is representation of my culture in terms of music which is not heard on mainstream radio." Many used words such as "a connection to your roots", "feeling grounded", and "home away from home" in relating their relationship to community radio. Using Castells' (1997) conception of identity, it can be argued that Caribbean Canadians are constructing their identity in and through community radio. Some used the term, "I'm reflected", to signify that what they have to say is important enough to be broadcast on community radio (O. Bailey, et al., 2008). They denote that there is a strong sense of belonging, and a sense that they own community radio: "Community radio is called community radio but it is our radio," and "I feel like I am the employer of community radio in the sheer giving and being part of the fundraising" (comments from interviewees). Bruce Girard (1992) substantiates their sense of ownership: 
While listeners of commercial radio are able to participate in the programming in limited ways - via open line telephone shows or by requesting a favourite song, for example - community radio listeners are the producers, managers, directors, evaluators and even owners of the stations. (Girard, 1992, p.2)

He further states that "this alternative form of radio is becoming increasingly important for those at the margins of society" (Girard, 1992, p.2) and that ethnic and linguistic minorities are 'transforming radio into a medium that serves their needs - a medium that allows them to speak as well as hear (p.2)'. One programmer noted the importance of her radio show to the French Creole community in the Greater Toronto Area:

People now know more about the French Creole community in the Caribbean. They are open to it and embrace it. There was a time when being Creole and speaking Creole was not hip, and a lot of people that came from the French Creole communities here were holding back and hiding underneath something else. They just didn't want to be identified with that, not everybody, and over the years with having the show at the station and just continually talking positive about being Creole, a lot of people have changed how they feel. I think that radio has made a difference and always will.

Community participation at all levels is important in the operation of community radio. Another listener noted that: "It [community radio] speaks to me, it speaks about my life and the life of my people, and also about other peoples that get forgotten. These include the native community, gay and lesbian community, the disabled community, and the women's community." She posited that a particular programmer on a show at CKLN was able to galvanize members of the black and Caribbean lesbian, gay, bisexual and 
transgendered community to attend a community forum with Pride Toronto, organizer of the annual Pride Week, to discuss the planned move of Blockorama from its current location to a smaller location. The organizer of Blockorama, a collective, Blackness Yes!, was upset with the impending move of what it considers as a space for black and Caribbean queers to celebrate their culture in the predominantly white, gay annual Pride celebrations.

In Understanding Alternative Media, Olga Guedes Bailey, Bart Cammaerts and Nico Carpentier (2008) posit that serving a community is one of four approaches to analyze community radio. The other approaches are: alternative media as an alternative to mainstream media, linking alternative media to civil society, and alternative media as a rhizome. The authors note that:

'Ordinary people' are given the opportunity for their voices to be heard, and take responsibility for distributing their own ideologies and representations. Topics that are considered relevant to the community can be discussed by members of the community. This empowers its members by signifying that their statements are considered important enough to be broadcast. Societal groups that are represented one-sidedly, disadvantaged, stigmatized, or even repressed can especially benefit from using the channels of communication opened by alternative media, to strengthen their internal identity, manifest this identity to the outside world, and thus enable social change and/or development. (O. Baileyet al., 2008, p.15)

They posit that, "a community is actively constructed by its members and those members derive an identity from this construction. This perspective also allows defining community as fluid and contingent, where the feeling of belonging to a community does 
not necessarily exclude affinities towards other communities or social structures (O. Bailey, et al., p.10)." One listener I interviewed notes that: "The author, the individuals who are telling the story look like me. The awareness of issues that community radio can bring to the community is very important. It has the potential to do great things but at the same time we have to hold it accountable."

Community radio physically and psychically connects first-generation Caribbean Canadians to the geographical place of their birth, but it also provides a framework of reference to second and third-generation Canadians of Caribbean descent. One listener notes that: "In Montreal, my parents would listen to get updates on what's happening in the Caribbean. It reminded me of how important the Caribbean was to my parents even though they lived in Montreal." As a result this listener volunteered at CKUT at McGill University when she was in grade $10 / 11$ of high school. Community radio creates the nostalgia of radio in the Caribbean for first-generation Caribbean Canadians, and provides a historical and contemporary reference for second and third-generation Caribbean-Canadians who advocate for more input from youth in community radio because they are the future leaders and the future market. Others expressed their frustration with their marginality on mainstream radio and noted that they feel included in community radio by the intrinsic access and participation available. Frances Berrigan (1977) posits that the need for access "stems from the perennial difficulty of the mass media, which are designed, on technical and economic grounds, to address mass audiences instantaneously, and to cater equally for all segments of their audience" (Berrigan, 1977, p. 16). 
The radio programmers make their programs accessible by doing various things, including a listener call-in segment to find out the location of the listener within the Greater Toronto Area, song requests and shout-outs (greetings) to family and friends. Listeners interested in producing programs at the radio stations will also receive production and on-air training. Those who are interested in the behind-the-scenes work of a radio station also receive training. There are produced, on-air announcements informing listeners of these opportunities. Some programmers have also added the use of new social networking tools like Twitter and Facebook, and video to extend their outreach. A few programmers mentioned the importance of maintaining their cultural integrity in terms of the use of their accents. They note that a lot of racialized minorities, or people of colour, work in community radio, and that community radio fill the void in mainstream media radio and television - by providing relevant programming for the Caribbean Canadian community in the Greater Toronto Area. Mainstream radio in Toronto is devoid of Caribbean accents:

The lack of radio that caters to the Caribbean community as a whole in Canada. The blatant hole that's sitting there. If it weren't for community radio, I don't know what we would do. We would probably end up like England, we would have pirate radio. There's a blatant lack of services when it comes to media television and radio for the Caribbean community. (an interviewed programmer)

Until we have a true 24-hour black radio station that has a sense of pride for being black, there's [sic] voids all throughout this big giant Toronto radio market in terms of satisfying people of Caribbean descent. It's easy to program towards 
those people because they are hungry all the time. They're always looking for food and the music is the food, especially music from the Caribbean that is misunderstood by commercial radio. Music is relevant to the people's lives. (another interviewed programmer)

Music is also important to many of the listeners. The programmers indicate that they do not play Top 20 songs but will program songs such as calypso and reggae that are political in nature. This is seen by them as a way of empowering the community by giving members a sense of who they are through music.

AMARC-Europe (O. Bailey, et al., 2008) describes a 'community radio station' as 'a "non-profit" station, currently broadcasting, which offers a service to the community in which it is located, or to which it broadcasts, while promoting the participation of this community in the radio' (Bailey, et al., 2008, p.7). The authors distinguish between participation in the media and through the media. "Participation in the media deals with the participation of non-professionals in the production of media output (content-related participation) and in media decision-making (structural participation)," note the authors (Bailey, et al., 2008, p.11). They posit that these forms of media participation allow citizens to be active in one of the many (micro-) spheres relevant to daily life and to put into practice their right to communicate (p.11). One listener notes that: "Community radio is holistic, circular, wrapped up in the common community. It's a give-and-take relationship. People who would never call a mainstream radio station will call community radio. People can speak in their own language." $\mathrm{A}$ programmer posits that: "The airwaves are a public good and radio is very accessible. The station celebrates the good things that are happening in the community. A radio 
station has the ability to bring a community up to speed in terms of the feelings, the perspectives, the views, in terms of what's going on. A radio station on a grassroots is just real, it's accessible." Participation through the media deals with the opportunities for extensive participation in public debate and for self-representation in public spaces (p.11). One programmer used his show in 1987 to invite to the on-air studio the mother of a young man who was shot dead by police. He used the show as a vehicle to raise money for the family. Others have discussed public issues such as the relevance of an Afrocentric school in the Toronto District School Board.

Mojca Plansak and Zala Volcic (2009) assert that the media are seen as a crucial player in the formation of identities, based on their role in providing space for (community) discussion and in helping sustain, suppress, or simply deal with cultural memories, myths, and collective fears, hopes, and desires for the future. It is the provision of space for community discussions, celebrations, and music from the Caribbean, or from Caribbean Canadian artists living in the Greater Toronto Area and beyond, that have sustained the Caribbean Canadian community in Toronto. Community media, in particular community radio, provide spaces of belonging for Caribbean people who occupy a marginal position in society (Frances Henry, 1994). Their fears, hopes, and desires for the future are expressed on community radio where they are able to participate in and through the media. One listener notes that she listens to community radio because it comes from the people: "There is no commercialism and radio personalities are seen on a regular basis doing things in the community - social justice work - stuff that really matters. I think it just gives a straight avenue to hear the real stories. Community radio is a closer connection than commercial radio." 
Using the explanation by O. Bailey, et al., (2008) of the concepts of participation in and through the media, it could be argued that Caribbean Canadians are using community radio for community cohesion. Their participation in community radio is allowing them to become active citizens in the (micro-) spheres relevant to their lives, and to put in practice their right to communicate (Ibid, 2008). First-generation, and second and third-generation Caribbean Canadians, ranging in ages from their 20s to 50s, listen to CHRY FM and CKLN FM and some have been doing so for more than twenty years. Though they might read community newspapers like Share, Pride and Caribbean Camera; and mainstream newspapers like the Toronto Star and the Globe and Mail, as well as online news sources, and listen to mainstream radio sometimes, and watch television, they all feel a connection to these community radio stations. One listener says: "I like the fact that community radio is an outlet that brings ordinary people together who are able to share and alert us to certain issues that are not usually heard in the mainstream media." Another notes that: "The programming is sensitive to the community and pulls in information about events happening Canada wide and also in Jamaica. I enjoy the open communication of community radio."

Referencing Benedict Anderson (1991), James Carey (1989), and Anthony Cohen (1985), among others, whose work focuses on the "symbolic construction of community", Kevin Howley (2010) notes the role of communication in creating a sense of shared identity and collective solidarity between disparate groups and individuals. He paraphrases Cohen's (1985) definition of communities as "expressions of commonality as well as difference" (Howley, 2010, p.64). Howley argues that, “[ ...] while commonsense understandings of community highlight the similarities within and between community 
members and their everyday lived experience, community life is far more diverse and our experience of community far more heterogeneous than we tend to acknowledge at first blush" (Howley, 2010, p.64).

Using cultural theorist Stuart Hall's (1986) concept of articulation, as speaking or enunciating, and the act of joining or combining separate elements, Howley argues that the feelings of affinity, belonging, "we-ness" that we share for our local neighbourhoods, ethic communities, or nationality are, in large measure, articulated within and through communication - broadly conceived - as in literature, performance, ritual, dress, and other symbolic forms and practices (Howley, 2010, p.64). Howley references Jennifer Daryl Slack's (1996) observation that, "Articulation is then, not just a thing (not just a connection) but a process of creating connections". Scholars interested in independent, alternative, citizens', and participatory media have argued that this emphasis on process, on practice, on the "doing" of community-based media underscores the relationship between communication and community building (Howley, 2010, p.65). One listener notes that: "Community radio brings the community together and allows me to hear programming from other cultures." Another notes that: “Community radio stations also have programming for different cultural groups that mainstream media do not. I am also able to verify information quickly by calling the radio station, especially on matters related to the community."

Caribbean Canadians are articulating and re-articulating their connection to place/space in the Greater Toronto Area to enhance community cohesion. As Henry (1994) posits Caribbean people wish to be a part of the plural structure of society while retaining those aspects of their ethnicity and culture that are important to them. Several of 
the listeners of CHRY FM and CKLN FM, as well as programmers and advertisers spoke of the connection that the radio stations provided to the community and to activism. In some instances, although the radio stations are situated in Toronto, they provide a psychological connection to the Caribbean. One listener notes: 'I like the feeling that the Jamaican programming gives me, I feel grounded. Its home away from home and I like that I have that backup to what I'm going to teach my children about home [Jamaica]." Another said: "It is important as a space and place for Caribbean immigrants to connect with what is happening back home in the Caribbean." The feeling of home transcends the time/space reality of living in Toronto. Howley (2010) notes that as an object of study, community media serve as an exceptional vehicle to explore the way local populations create media texts, practices, and institutions to serve their distinctive needs and interests.

The training that these radio stations provide to listeners also creates a connectedness to the community. The ordinariness of the creators of the programs, the accents and languages spoken create a familiar atmosphere for many Caribbean Canadians. Many have said that they hear issues relevant to their lives being discussed on these radio stations and they can call in to participate. "I don't feel like I'm outside looking in. I hear myself or someone that I would not hear on mainstream radio," says one listener. When they call in there is direct connection to the programmer as there is no one to screen their call. There is no gatekeeper to keep them away from the local on-air host or programmer. Some respondents have said that they are kept up-to-date of events happening in the community, and feel that they are a part of a larger Caribbean, and/or Black community. In some instances, older generations recommend that the younger generation listen to particular programs on the radio stations. In many cases, the listeners 
appreciate the two-way communication that they can have with the in-studio radio host. One respondent noted that there is still a sense of localness to it [community radio] that you don't get on Internet radio. Some are prompted to take action, to support a cause or participate in a grassroots rally or event, after listening to community radio. Some talk back to it, and thus are involved in the "doing" of community radio which provides them with a sense of belonging, a sense of community cohesion.

Howley (2010) notes that dominant media habitually misrepresent or underrepresent individuals and groups based on distinctions of race, class, gender, ethnicity, and lifestyle. For those with little or no access to mainstream media outlets, community media provide resources and opportunities for marginalized groups to tell their own stories, in their own voices, and using their own distinctive idioms (Rodriquez, 2001).

In doing so, community media are instrumental in protecting and defending cultural identity while simultaneously challenging inaccurate, prejudicial, and otherwise unflattering media representations. Thus, through the production and dissemination of media texts that assert and affirm cultural identities, and otherwise challenge the ghettoization (Downing \& Husband, 2005) of marginalized groups, community media can make visible cultural differences in discursive as well as social space. (Howley, 2010)

Caribbean Canadians have little access to mainstream media and when faced with the reality of being misrepresented or underrepresented by their race or ethnicity (Henry, 1994), they have chosen to use community radio to tell their own stories. Many listeners in this research study referenced their distinctive idioms that are heard on community 
radio but which are absent from mainstream media and the public broadcaster, the Canadian Broadcasting Corporation. Advertisers to the Caribbean Canadian community on these community radio stations would agree with the assertion below that community media address the diverse tastes and interests of minorities.

In Western Europe, Canada, and Australia - where public service broadcasters enjoyed monopoly status throughout much of the $20^{\text {th }}$ century - community media challenge the public broadcaster's construction of a unified, homogeneous national identity by addressing the diverse tastes and interests of ethnic, racial, and cultural minorities that are often ignored, silenced, or otherwise misrepresented by national broadcasters (Berrigan, 1977, quoted in Howley, 2010, p.2)

One advertiser asserts that these radio stations are speaking to the people and providing the music that they want to hear, as well as the use of their language, thus giving them a voice. Another notes that in the mainstream media, the dissemination of information about the community is generally negative, and therefore community media are critically important to the community. They communicate the work, thoughts and issues of Caribbean Canadians which are absent from mainstream media and the public broadcaster. Issues of exclusion, social justice, policing, housing, employment, education, immigration and settlement are some of the concerns of this community.

The Caribbean Canadian community in the Greater Toronto Area is not a monolithic group and therefore within the community there are diverse views about the role of community radio. Some respondents expressed concern that there is a generational gap between the radio stations and the younger generation. They assert that the survival 
of these radio stations lie in the youth who are the future leaders of tomorrow. They want to hear about positive things happening in at-risk communities and about more youthrelated partnerships. Some would like the radio stations to be participating in more outreach projects in local schools and at community events. A young listener notes:

If you're outside of university, do you listen to community radio? Outside of the music, do I want them to listen to the other programming? There needs to be a campaign to get their brands out. Community radio needs to identify the new and emerging voices out there. In doing that, they bring with them a generation, a new listenership to community radio.

Referencing the genres of music that he plays on his show, one programmer notes that: "It is music that empowers youth, music that gives people a sense of who they are. Dancehall is like the new Hip Hop - highly political - the essence of what's going on in the streets."

In identifying the cohesive influence of community radio, some respondents noted that in the Caribbean the radio is constantly on and people listen. They assert that the programs are quite spirited, people call in to the programs and are quite passionate and vocal. Some Caribbean Canadians argue that a similar kind of experience can only be found in Canada on community radio. Hosts of the radio shows targeting the Caribbean Canadian community spend a lot of time producing shows which connect with Caribbean causes. At times there is commentary in the music which is relevant to a particular event or cause in the Caribbean or pertaining to issues affecting the Caribbean Canadian community in the Greater Toronto Area. Programmers are out and about in the 
community ensuring that they know the issues and events that are important to Caribbean Canadians. They disseminate that information on their programs.

Applying Castells (1997) notion of resistance identity, one could argue that Caribbean Canadians having been stigmatized by the logic of domination in society, have built trenches of resistance and survival. I am arguing that their access to and participation in community radio is one of the ways that they are countering their marginalization in society. Henry (1994) alludes to the fact that Caribbean people are in the process of becoming institutionally complete by developing services to meet their own needs. While they are not the total owners of CHRY Radio and CKLN Radio, one could argue that they are creating their own institution (community radio) and are attempting to maintain aspects of their culture and ethnicity (Henry, 1994). Some of the respondents in this study said they felt as if they owned the radio station, especially during the annual on-air fundraising drive when they donate money to the station. Some have demonstrated their loyalty to community radio by setting aside money from their salary, in advance, to donate to the annual fundraising period in the radio stations' calendar.

There are some people who because of the low wattage of CHRY Radio do not receive the transmission clearly in their homes, but will drive around or sit in their cars in their driveway for three hours to listen to entire Caribbean programs. The hosts of the programs are from the Caribbean Canadian community and ensure that they keep connected to listeners by inviting individuals from the community onto their shows. They buy music from local community stores and are tapped into the informal, as well as formal, community information network. Some would like to participate in more remote 
broadcasts which actually take them into the community and further their connection to listeners. "Being from the community and having members from the community on the show, there's kind of a reciprocal effect. If something happens within the community, like a travesty, the programmer will talk about it. Programmers are accessible," says one programmer. This is a sentiment that was replicated by many more programmers.

Deuze (2006) notes the importance of community members creating their own media, or becoming the media, which refers to a perspective on the media audience as active producers of meaning from within their own cultural context. Caribbean Canadians are not only on the receiving end of community radio, as listeners. They are actively producing radio programs and are integrally involved in the decision-making practices of these media at the board and operational levels. Some said community radio did remote broadcasts from the annual Caribana Parade long before mainstream media started doing so. They also noted that it was a totally different perspective provided by community radio because the people involved in the broadcasts were not experts analyzing Caribbean culture, but Caribbean Canadians who were practitioners of the art of carnival.

Some programmers have recognized the potential for members of the Caribbean Canadian community to be parochial or nationalistic in their view of the community. They have produced their programs to be Pan-Caribbean in nature and content. Some start their shows by greeting, or sending shout-outs, to listeners originating from every Caribbean country. They name each country and include music from the various countries in their programming. One programmer was quick to remind me that the Caribbean is not made up only of Afro-Caribbeans, but also Indo-Caribbeans and others, which he includes in his programming. "In as much as Canada highly promotes the 
multicultural, diverse nature of Canada and especially of Toronto, Canada really does lip service to that. The Canadian media, in general, is white dominated, male dominated, and that's the perspective you get," said one programmer who believes that Caribbean Canadians find something in the programming on community radio that connects to their soul. O. Bailey, et al., (2008) note that diasporic groups have distinct uses for alternative media, depending on their particular situations, such as their reasons for migrating to a new country, differences in terms of class, age, gender, ethnicity, and so on.

Diasporic audiences tend to form 'communities' bound by some degree of common political and social interests, and by ethnicity, language, and culture. Moreover, they may produce and use these media as political instruments to voice concerns about their exclusion from the main public sphere, to maintain connections with their countries of origin and to build and sustain a new local and transnational 'imagined' community. Overall, the diversity of their media practices functions to help these communities in the process of identity negotiation - individual and collective new hybrid identities - between the homeland and the host country's societies, rules, and rituals. (O. Bailey, et al, 2008, p.150)

Caribbean Canadian candidates running for office at the municipal, provincial or federal level of government appear on Caribbean-programmed shows at these radio stations to appeal for support. Call-in shows are done with these candidates as guests and they are able to get direct feedback, or reaction from listeners, regarding their election campaign. Some listeners are also concerned about the future of community radio in this era of media consolidation, commercialization, and the reduction of local media. CARN 
(Caribbean and African Radio Network) recently tested its signal at 98.7 FM and there are concerns among some listeners who support CARN and community radio that programmers will move to the commercial entity, CARN. Some, however, see young people interested in community radio then moving in to fill the vacant slots left by programmers. Still others expressed a desire for a 24-hour radio station dedicated to Caribbean programming. Some are also concerned about what they see as the encroaching power of commercialization on community radio. They are concerned about what community radio may have to give up, to ensure its survival. Still others believe that things have to be done differently to accommodate youth participation in the radio stations. Some listeners identified the lack of resources of community radio and the unprofessionalism of many of the programmers. The listeners recognize the minimal physical resources of these stations and wish they had more. They also want the programmers to be more professional in their presentation of the programs. In describing the programming of community radio, Girard (1992) notes that: "It is not important that the programming be "slick," but that it be based on a concept of participatory communication. The role of the radio is to respond to the priorities set by the community, to facilitate their discussion, to reinforce them, and to challenge them (Girard, 1992, p.3)." He also underscored the point that juggling all the interests of a community is difficult, and community radio does not always succeed (Girard, 1992, p.3). Indeed, some of the listeners think that programmers should challenge the views of individuals from within the Caribbean Canadian community who appear as guests on some programs to speak on controversial issues. At times there are some issues that are so controversial that both programmers and listeners believe that their 'dirty laundry must not be washed in 
public'. They believe that some things must be discussed within the community and when it is broadcast it becomes susceptible to various interpretations and possibly to further stereotyping of the Caribbean Canadian community. These usually relate to incidents that happen at events organized by individuals within the community.

All of the respondents in this research study emphasized the alternative role, or oppositional role, that community radio play vis-à-vis mainstream media. Their presence in this country and their stories are validated on community radio. According to Minelle Mahtani (2001):

Canadian media continue to broadcast negative and stereotypical images that only serve to demean minority Canadians. In other words, ethnic minorities do not see themselves accurately reflected in Canadian media, and that marginalization perpetuates feelings of exclusion-especially when we place value upon those representations as fair and equitable mirrors of our nation.

It is precisely because of the negative representation or misrepresentation in mainstream media that many Caribbean Canadians support the community radio stations, CHRY FM and CKLN FM. As one programmer in this research study states:

Most times you see Caribbean people, and people like Caribbean people, we're being served, we're being helped, we're being jailed, we're being bad, we're being negativized. This program flips that. This program says I can listen to that guy on the radio and feel proud.

Cultural theorist and sociologist Stuart Hall, (1981) in examining racist ideologies and the media posits that: "Racism and the media touches directly the problem of ideology, since the media's main sphere of operations is the production and 
transformation of ideologies" (Hall, 1981). He notes that an intervention in the media's construction of race is an intervention in the ideological terrain of struggle (George Bridges and Rosalind Brunt (Eds.), 1981; p. 31). According to Hall, ideology is a practice, and is generated, produced and reproduced in specific settings (sites), especially, in the apparatuses of ideological production which 'produce' social meanings and distribute them throughout society, like the media. Community media, including community radio, are involved in intervening in the mainstream media's construction of race. That is what the aforementioned radio programmer meant by "This program flips that," when he mentioned the counterbalancing role that his program plays in relation to mainstream media. Hall (1981) notes that, "How we 'see' ourselves and our social relations matters, because it enters into and informs our actions and practices." $\mathrm{A}$ respondent described mainstream media as being narrow in their perspective, very racist, very sexist, exclusive and not accessible. Another said the programming of community radio is sensitive to the community. Though marginalized, Caribbean Canadians are revisioning their position in Canada, and are transforming the discourses about them as they tell their own stories, in their own voice on community radio.

Augie Fleras (2009) notes that: "Despite modest moves toward improving diversity depictions, the newsnorms of a conventional news paradigm continue to frame minorities as troublesome constituents, that is, problem people who are problems who have problems and who create problems (Fleras, 2009, p.143)." Fleras also underscores the value that multicultural minorities and aboriginal peoples find in alternative media by noting that in mainstream media: 
They continue to be rendered invisible except in contexts of crisis, negativity, or conflict, in the process reinforcing their status as troublesome constituents for removal or control. To circumvent or neutralize the effects of this systemically biasing coverage, ethnic (or 'racialized') minorities and aboriginal peoples have turned to alternative media institutions. (Fleras, 2009; p.144)

Caribbean Canadians are circumventing or neutralizing the 'systemically biasing coverage' by being involved as producers (content providers) at community radio stations.

\section{Conclusion}

CHRY and CKLN are clearly involved in the process of ensuring that there is a space and place for marginalized voices in Toronto, especially the voices, accents and all, of people from the Caribbean. Their views and experiences are valorized on campus/community radio stations where they have found a welcoming space for their identity and difference. Lionnet posits that spaces like these engender more fulfillment in life because of the presence of diverse languages.

Variety and heterogeneity lead to richer and more fulfilling lives for all those who share a given environment, multiplicity flourishes when the shackle of homogeneity and rigidity are broken. By contrast, to internalize patriarchal law is to create mutually exclusive categories of "reality" (male/female; white/black; 
primitive/civilized; autobiographical/fictional; etc.) and to forget that the production of discourses can function according to Darwinian divergence: that a given space (text) will support more life (generate more meanings) if occupied by diverse forms of life (languages). (Lionnet, 1989, pp. 17\&18)

CHRY and CKLN have provided a counterideology to the dominant narrative of people emigrated from the Caribbean to Canada as 'other' whose voices need not be heard on mainstream radio. Like Canadian authors, Austin Clarke, Dionne Brand, M. Nourbese Philip, Lillian Allen and Afua Cooper-- all from the Caribbean-CHRY's and CKLN's Caribbean programmers and listeners are articulating their presence in Canada, their home and native land. They have embraced survival tactics and strategies and strategies that have inscribed them in Canada's broadcasting system. Many, however, are still waiting to hear themselves reflected on the public broadcaster and on the privatelyowned commercial radio stations in the Greater Toronto Area. 


\section{REFERENCES}

AMARC. Final Narrative Report: AMARC Community Radio Impact Evaluation:

Removing Barriers, Increasing Effectiveness. February 15, 2007.

Atton, C. (2002). Alternative Media. London: Sage.

Bailey, O., Cammaerts, B., \& Carpentier, N. (2008). Understanding Alternative Media.

Berkshire: Open University Press.

Berrigan, F. (1977). Access: Some western models of community media. Paris: UNESCO.

Berrigan, F. (1981). Community Communications: the role of community media in

development. Reports and papers on mass communication; No. 90. Paris: UNESCO

Bosch, T.E. (2003). Radio, community and identity in South Africa: a rhizomatic study of Bush Radio in Cape Town (Ph.D., Ohio University)

Burman, J. (2010). Transnational Yearnings: Tourism, Migration, and the Diasporic

City. Vancouver: UBC Press

Cammaerts, B. (2009) Community radio in the West: a legacy of struggle for survival in a state and capitalist controlled media environment. International communication gazette, 71 (8). pp. 635-654.

Carpentier, N. (2008). The Belly of the City: Alternative Communicative City Network. In International Communications Gazette, Vol. 70, No. 3-4, 237-255. 
Castells, M. (1997). The Information Age: Economy, society and culture, vol. II, the power of identity. Mass.: Blackwell Publishers.

CHRY Community Radio Inc. Oral Presentation to the Canadian Radio-Television and Telecommunications Commission. (Re: an application by J. Robert Wood (OBCI) for a licence to carry on an FM broadcasting undertaking in Toronto. February 4, 1988).

CHRY Community Radio Inc. Supplementary Brief - CHRY Community Radio Inc. Application for Frequency 105.1 MHz. September 9, 2002.

CKLN. Program Guide 2007/2008

CHRY. "Waves You Crave". Fundraising drive 2008 - October $11^{\text {th }}$ to $25^{\text {th }}$.

Canadian Radio-television and Telecommunications Commission (CRTC). Broadcasting Regulatory Policy CRTC 2010-499. Retrieved on July 25, 2010 at www.crtc.gc.ca/eng/com 100/2010/r100722.htm

CRTC. CRTC Decision 87 - 240. CHRY Licence Renewal Application. January 1990 CRTC. Policy Proposals for Community and Campus Radio. Public Notice CRTC 1991118

CRTC. Broadcasting Notice of Public Hearing CRTC 2002-8 (application by A. Fitzroy Gordon ("Applicant" or "CARN").

Couldry, N., \& Curran, J. (2003). Contesting media power: Alternative media in a networked world. New York: Rowman and Littlefield.

Creswell, J. (1998). Qualitative Inquiry and Research Design: Choosing Among Five Traditions. Thousand Oaks, London, New Delhi: Sage.

De Certeau, M. (1984). The Practice of Everyday Life. Trans. Steven Rendell. Berkeley: University of California Press. 
Denscombe, M. (2007). The Good Research Guide for small-scale social research projects. Berkshire: Open University Press.

Deuze, M. (2006). "Ethnic Media, community media and participatory culture". In Journalism, vol. 7, no.3, 262-280.

Fairchild, C. (2001). Radio and Public Culture: Being an examination of media access and equity in the nations of North America. Cresskill, N.J.: Hampton Press.

Fairchild, C. (1993). "The Producers and the Produced: Community radio in Toronto". Master's Thesis. York University: Toronto.

Fleras, A. (2009). Ethnic and Aboriginal Media in Canada: Crossing Borders, Constructing Buffers, Creating Bonds, Building Bridges. In R. Geissler and H. Pottker (eds.), Media Migration Integration: European and North American Perspectives. Verlag, Bielefield Foster, C. (1996). A Place Called Heaven: The meaning of being black in Canada. Toronto: HarperCollins.

Fraser, N. (1990). 'Rethinking the Public Sphere: A contribution to the critique of actually existing democracy'. Social Text, No. 25/26, 56-80

Fuller, L. (2007). Community media: international perspectives. New York:

Palgrave Macmillan.

Girard, B. (Ed.). (1992). A Passion for Radio: Radio waves and community. Montreal: Black Rose Books Gramsci, A. (2000). The Gramsci Reader: Selected writings, 1916-1935. Forgasc, D. (Ed.) New York: New York University Press 
Habermas, J. (1989). The Structural Transformation of the Public Sphere: An inquiry into a category of bourgeois society. Cambridge: MIT Press

Hall, S. (1993). "Cultural Identity and Diaspora." In Identity, Community, Culture, Difference. (Ed.) Jonathan Rutherford. Lawrence \& Wishart: London Hall, S. (1981). "The Whites of Their Eyes: Racist ideologies and the media." In Silver linings: Some strategies for the eighties: Contributions to the Communist University of London. (Eds.) George Bridges and Rosalind Brunt. London: Lawrence and Wishart. Henry, F. (1994). The Caribbean Diaspora in Toronto: Learning to live with racism. Toronto: University of Toronto Press Howley, K. (Ed.) (2010). Understanding Community Media. Los Angeles: Sage Howley, K. (2005). Community media: people, places, and communication technologies. Cambridge, UK ; New York: Cambridge University Press.

James, C. \& Shadd, A. (Eds.) (2001). Talking about Identity: Encounters in race, ethnicity, and language. Toronto: Between the Lines.

Jankowski, N. (2002). "Creating Community with Media: History, Theories and Scientific Investigations". In The Handbook of New Media: Social shaping and consequencies of ICTs. London: Sage.

Karim, K. \& Samson, G. (1990). Ethnicity and the mass media in Canada: an annotated bibliography. Ottawa: Policy \& Research, Multiculturalism Sector, Multiculture \& Citizenship.

Klaehn, J. (Ed.) (2005). Filtering The News: Essays on Herman and Chomsky's propaganda model. Montreal: Black Rose Books 
Lewis, P., \& Jones, S. (Eds.) (2006). From the margins to the cutting edge: community media and empowerment. Cresskill, N.J.: Hampton.

Lionnet, F. (1989). Autobiographical Voices: Race, gender, self-portraiture. Cornell University Press

Lorimer, R. \& Wilson, D. (Eds.) (1988). Communication Canada: Issues in broadcasting and new technologies. Toronto: Kagan and Woo Limited

Mainali, R., Yadab Chapagaini \& Bikram Subba. (2009). Community radio: Performance assessment system. Radio Knowledge Centre, Community Radio Support Center (CRSC)/Nepal Forum of Environmental Journalists (NEFEJ) with support from Free Voice, The Netherlands.

Mahtani, M. (2001). Representing Minorities: Canadian Media and Minority Identities. Commissioned by the Department of Canadian Heritage for the Ethnocultural, Racial, Religious, and Linguistic Diversity and Identity Seminar. Halifax, Nova Scotia. Nov. 1-2, 2001

McLuhan, M. (1964). Understanding Media: The extensions of man. New York: Mentor Monk, L. (1977). “Beyond polarity: Campus-community radio and new relations of power in radio broadcasting policy in Canada". Master's Thesis. Concordia University, Quebec.

Mosco, V. (1996). The Political Economy of Communication: Rethinking and renewal. London: Sage

National Campus and Community Radio Association. "About campus/community radio." www.ncra.ca 
Plansak, M., \& Volcic, Z. (2009). "Reimagining National Belonging with Community Radio". In Understanding Community Media. Howley, K. (2009). Los Angeles: Sage. Rennie, E. (2006). Community Media: A global introduction. Lanham, MD: Rowan \& Littlefield.

Skinner, D. (2010). "Minding the growing gaps: Alternative media in Canada". In Shade, Leslie Regan. Mediascapes: new patterns in Canadian communication. Toronto: Nelson Education

UNESCO. "Metro Toronto's Changing Communities: Innovative Responses Canada". In MOST Clearing House Best Practices Database. Retrieved at www.unesco.org/most/usa9.htm on August 13, 2010

Van Vuuren, K. (2006). 'Community broadcasting and the enclosure of the public sphere'. In Media, Culture \& Society. Vol. 28(3): 379-392. London: Sage

Williams, R. (1980). Culture and Materialism: Selected essays. London: Verso 


\section{Appendix A}

\section{CHUM Radio buys Toronto's New Flow 93.5 FM from Milestone}

By: The Canadian Press

$23 / 06 / 2010$

TORONTO - CTV-owned CHUM Radio is buying Toronto radio station New Flow 93.5 FM from Milestone Radio Inc. for undisclosed amount.

CHUM said Wednesday that FLOW, which launched in February 2001 as Canada's first urban music station, "has established itself in Toronto as a leader in delivering unique urban programming with a focus on discovering and promoting local artists."

"Flow has done a great job carving out a niche in the Canadian radio landscape providing unique opportunities to artists, listeners and advertisers," CHUM president Chris Gordon said in a statement.

"We value the contributions FLOW has made to promote and develop new Canadian artists, and we look forward to working with their team to grow the station and continue to service the community in Toronto."

The sale requires regulatory approval.

CHUM is a division of CTV Ltd., itself part of the CTVglobemedia family of media properties. It operates 34 radio stations in 16 markets across Canada.

It was the third radio station deal in recent days, following an announcement Rogers Communications (TSX:RCI.B) Tuesday that it is preparing to buy Bounce FM in Edmonton and on Monday that it would buy BOB-FM in London, Ont., both from CTV. Rogers operates 13 radio stations in Alberta, and a total of 53 radio stations across the country on both the AM and FM dial. 


\section{APPENDIX B}

\section{CARN'S TESTING OF 98.7FM \\ FREQUENCY WAS SUCCESSFUL*}

June 21, 2010

Hello CARN Listeners,

I am happy to share with you the good news that the testing of the 98.7 FM radio

frequency has been successfully completed. From all reports, CARN 98.7FM had a clean and penetrating sound except for certain areas in the East where we experienced some interference from a CBC station.

We are hoping that this will be rectified in time.

CARN was authorized by Industry Canada to conduct testing of this frequency for a 3 week period beginning May $31^{\wedge}$ st and ending June $21^{\wedge}$ st at 11:59 PM. The testing was independently carried out by Canada's largest broadcasting consulting engineering firm which reported that they found no interference to any existing radio station including the $\mathrm{CBC}$.

During this testing period, CARN played some of the most beautiful music that has not been on the playlists of Canadian mainstream commercial radio stations. Your response to this music has been tremendously positive. In fact, the thousands of emails, telephone calls and Facebook comments confirms that there is a great need for this radio format in the GTA. This reassurance has made my 12 year battle to bring this radio station to the GTA worthwhile. Allow me to share with you two of the thousands of great comments we have received:

I "I have been living in Canada for more than 40 years, I never thought I would see the day when I would turn my radio on and hear R\&B, Soul, Reggae, Soca and Gospel in the middle of the day on a mainstream station in Toronto. It brought tears to my eyes. Thank you CARN you have made

my day." -- Listener from downtown Toronto, Ontario./

/"I would just like to let you know that my mother and I stumbled across 98.7 today while trying to find another station that we usually listen to. Am I glad that we didn't find that station because the music on 98.7 was so sweet it has inspired my VERY reserved mother to let loose and have a BBQ. This station is awesome! We couldn't stop listening to it.There's nothing like this on Canadian radio. Keep up the good work, you guys are awesome. We are praying that this is more than a test, but a TESTIMONY of the great beginning of 98.7 !" -- Listener from Brampton, Ontario./

I thank all of you from the bottom of my heart for your inspiring words of support. 
Where do we go from here? Now that the testing has been successful, I must return to the CRTC to attain that final official broadcast certificate which will allow CARN to start its long awaited broadcast operation. Our vigilance is still needed as the $C B C$ maintains its resistance to us having our own radio station by claiming that our station could cause interference to their Peterborough station. Clearly the independent testing has proven that it is the other way around. I am quite sure that the Government of Canada, Industry Canada and The CRTC understands the great need for the Black and Caribbean population of the GTA to have its own radio station.

While our on-air broadcasting will end on June 21^st @ 11:59PM as per Industry Canada testing authorization, our goal is to be back on the air and fully launched as soon as possible. We are working hard to have our new website www.CARN987.com $<$ http://www.CARN987.com> launched shortly

which will provide up-to-date information on our progress, the official launch date, employment opportunities and on-line live music streaming.

Your strong concerns regarding CARN 98.7FM changing its format once we've launched has been heard loud and clear. Please be assured that this has strengthened my resolve to protect this format on your behalf.

While I understand and feel your frustration I must say that I feel like a child being spanked for the wrongs done by another, but I understand and will take heed. CARN 98.7FM will be the station to provide you with your music, news, sports, and talk shows. I agree with all of you that this radio format is long overdue. We look forward to serving you for a long time to come.

Thank you and God Bless,

Fitzroy Gordon

Founder \& President

CARN Radio Toronto 


\section{Appendix C}

\section{Proposed FM station says CBC in its way}

Tuesday, September 11, 2007

\section{CBC News}

The Caribbean and African Radio Network is upset with the CBC over what it says is the public broadcaster's "selfishness."

The network wants to establish a station at $98.7 \mathrm{FM}$, but that frequency is extremely close to Toronto's CBC 99.1 radio station.

CARN president Fitzroy Gordon held a news conference on Monday to publicly complain about the CBC. He said the goal of CARN is to provide news, features and music from Caribbean communities at home and abroad. "Our community is the largest community in the GTA without a radio station designated to serve this community," he said.

In a news release Gordon said his organization is "frustrated, disgusted, angry and ashamed of the selfishness of the public broadcaster" for its stand.

The CRTC granted temporary approval in April 2006, but on condition the network find a spot on an already crowded FM dial. Gordon said the best chance to reach communities from Ajax to Oakville is at 98.7 .

Broadcast regulations give nearby neighbours veto power if they feel the arrival of a new station might have an impact.

Jeff Keay, the head of media relations for $\mathrm{CBC}$, said the public broadcaster has no issue with CARN's plans for a radio station, and the only issue is a technical one. Keay said "98.7 is just two steps from 99.1 and would create interference for us, for our listeners."

Gordon doesn't appreciate the CBC's opposition. CARN said the CBC has produced no technical evidence to support its claim, but Keay said it's an established industry standard.

The CRTC temporary licence has now expired, but the Caribbean and African Radio Network is still focused on $98.7 \mathrm{FM}$, calling it the best remaining frequency in the GTA. Gordon is promising to continue his fight to obtain the frequency. 
Read more: http://www.cbc.ca/canada/toronto/story/2007/09/11/carnfm.html?ref=rss\#ixzzOu41ZDU6b 